\title{
Keterlaksanaan Pembelajaran Fisika Implementasi Kurikulum 2013 Berdasarkan Latar Belakang Akademik Guru
}

\author{
Ninik Uswatun Fadilah ${ }^{1} *$, Suparwoto ${ }^{2}$ \\ ${ }^{1}$ MAN Wonosari. Jalan Sunan Ampel No 68, Trimulyo, Kepek, Gunungkidul, Yogyakarta, Indonesia. \\ ${ }^{2}$ Jurusan Pendidikan Fisika, Universitas Negeri Yogyakarta. Jalan Colombo No. 1, Karangmalang, \\ Yogyakarta 55281, Indonesia. \\ * Korespondensi Penulis. Email: ninik_fadilah@yahoo.com
}

\begin{abstract}
Abstrak
Penelitian ini bertujuan untuk mengetahui keterlaksanaan pembelajaran fisika di MAN pilot project DIY dalam implementasi Kurikulum 2013 berdasarkan latar belakang akademik guru ditinjau dari (1) pemahaman terhadap Kurikulum 2013, (2) perencanaan, (3) pelaksanaan, (4) penilaian, (5) upaya yang dilakukan untuk meningkatkan pemahaman pada implementasi Kurikulum 2013 dan (6) hambatan yang dihadapi pada implementasi Kurikulum 2013. Jenis penelitian ini merupakan penelitian survei dengan pendekatan deskriptif kualitatif dan kuantitatif. Populasi penelitian ini adalah guru fisika kelas X di MAN pilot project DIY yang menerapkan Kurikulum 2013. Teknik pengumpulan data yang digunakan adalah angket, observasi, wawancara dan dokumentasi. Hasil penelitian menunjukkan bahwa pemahaman mengenai Kurikulum 2013 berada pada kategori sangat baik. Perencanaan berada pada kategori baik, pelaksanaan berada pada kategori baik, penilaian berada pada kategori baik. Upaya guru fisika di MAN pilot project di DIY yaitu mencari informasi mengenai rasionalisasi kurikulum 2013, pendekatan saintifik, administrasi pembelajaran dan penilaian otentik baik secara mandiri maupun dari kegiatan pelatihan. Hambatan yang dihadapi guru yaitu kurangnya ketersediaan buku/panduan mengenai pendekatan saintifik, guru kesulitan dalam membuat instrumen penilaian portofolio, dan guru belum maksimal dalam memfungsikan instrumen penilaian sikap.
\end{abstract}

Kata Kunci: keterlaksanaan, Kurikulum 2013, latar belakang akademik guru

\section{The Feasibility of the Physic Learning Process in Implementing Curriculum 2013 Based on the Teachers' Academic Background}

\begin{abstract}
This study aims to determine the feasibility of the physic learning process in implementing Curriculum 2013 based on the teachers' academic background at the pilot project MAN in DIY in terms of (1) understanding of the Curriculum 2013, (2) planning stage, (3) implementation stage, (4) assessment stage, (5) the effort of the phisycs teachers in pilot project MAN to integrat the knowledge about Curriculum 2013 in phisycs learning process; (6) the obstacles found by the phisycs teachers in the implementation of Curriculum 2013. This research was survey research with descriptive qualitative and quantitative approach. The research population was phisycs teachers of class $X$ of pilot project MAN in DIY which implemented Curriculum 2013. The technique of data collection was questionnaires, observation, interviews, and documentation. The results show that the teachers' knowledge of Curriculum 2013 is very good. The planning is in the quite good category, the implementation is in the good category, the assessment is in the good category. the efforts of physics teachers at pilot project MAN are looking for information about: the rationalization of the Curriculum 2013, the scientific approach, the administration of learning and authentic assessment either independently or by training program; (4) the obstacles found by the teachers are: the lack of availability of the book/guide on Problem Based Learning (PBL), Project Based Learning (PjBL) learning model, the teachers difficulty in making portfolio assessment instruments, and the teachers have not been able to maximal functioning of attitude assessment instruments.
\end{abstract}

Keywords: the feasibility, Curriculum 2013, teachers' academic background

How to Cite: Fadilah, N., \& Suparwoto, S. (2016). Keterlaksanaan pembelajaran fisika implementasi kurikulum 2013 berdasarkan latar belakang akademik guru di MAN DIY. Jurnal Inovasi Pendidikan IPA, 2(1), 76-87. doi:http://dx.doi.org/10.21831/jipi.v2i1.8380

Permalink/DOI: http://dx.doi.org/10.21831/jipi.v2i1.8380 


\section{PENDAHULUAN}

Pendidikan nasional, sebagai salah satu sektor pembangunan nasional dalam upaya mencerdaskan kehidupan bangsa, mempunyai visi terwujudnya sistem pendidikan sebagai pranata sosial yang kuat dan berwibawa untuk memberdayakan semua warga negara Indonesia berkembang menjadi manusia yang berkualitas sehingga mampu dan proaktif menjawab tantangan zaman yang selalu berubah (Kemdikbud, 2012a). Menurut Undang-Undang Nomor 20 Tahun 2003 tentang Sistem Pendidikan Nasional, makna manusia yang berkualitas adalah manusia yang beriman dan bertaqwa kepada Tuhan Yang Maha Esa, berakhlak mulia, sehat, berilmu, cakap, kreatif, mandiri, dan menjadi warga negara yang demokratis serta bertanggung jawab.

Pendidikan nasional saat ini dihadapkan pada berbagai permasalahan yang perlu untuk dicari pemecahannya. Permasalahan tersebut berupa tantangan internal dan tantangan eksternal (Kemdikbud, 2012b). Selain hal tersebut, ada kecenderungan saat ini peserta didik belum optimal dalam internalisasi nilai-nilai kehidupan secara matang dan bermakna. Hal ini disebabkan dalam proses pembelajaran masih menitikberatkan pada aspek kognitif, dengan aspek afektif dan psikomotorik yang bermuatan karakter belum mendapat perhatian. Pada aspek pembelajaran di sekolah masih berorientasi penguasaan materi untuk persiapan menghadapi ujian nasional (Kunandar, 2013, p.18). Sebagai solusinya diperlukan implementasi pembelajaran yang dapat menyeimbangkan antara penguasaan kognitif dan pendidikan karakter, dengan harapan produk pendidikan selain diperoleh manusia yang cerdas secara kognitif juga memiliki karakter spiritual yang baik. Kombinasi dua hal tersebut diduga dapat menjadi bekal bagi peserta didik untuk memenangkan kompetisi dalam dunia global.

Menyikapi permasalahan-permasalahan tersebut diperlukan perubahan dalam komponen implementasi pembelajaran yang berbasis karakter dalam pendidikan nasional. Salah satu komponen yang terkait dengan sarana pendidikan adalah pemilihan kurikulum yang diterapkan. Kurikulum perlu dijadikan acuan oleh setiap satuan pendidikan.

Republik Indonesia telah mengalami beberapa kali penyempurnaan dan perubahan kurikulum. Dimulai dari kurikulum tahun 1947 sampai dengan yang terbaru ini adalah perubah- an pada tahun 2013 yang dikenal dengan Kurikulum 2013. Kurikulum ini merupakan langkah lanjutan implementasi Kurikulum Berbasis Kompetensi yang dirilis pada tahun 2004 dan KTSP 2006 yang mencakup kompetensi sikap, pengetahuan, dan keterampilan secara terpadu (Warso, 2014, p.10). Perubahan ini dimulai dengan penataan terhadap empat elemen Standar Nasional, yaitu Standar Kompetensi Lulusan (SKL), Standar Isi (SI), Standar Proses Pembelajaran (SPP), dan Standar Penilaian (SP).

Cheung \& Wong (2011, p.44) mengungkapkan bahwa ada beberapa faktor yang mempengaruhi implementasi kurikulum. Faktorfaktor tersebut merupakan komponen-komponen penyusun suatu sistem yang menentukan keberhasilan suatu kurikulum, salah satunya adalah faktor guru. Senada dengan Cheung \& Wong, Purnomo (2013) menyatakan bahwa para guru perlu memahami struktur dan substansi Kurikulum 2013, menguasai aspek perencanaan, pelaksanaan dan penilaian pembelajaran.

Mengenai faktor dari guru Yuhetty dan Miarso (2008, p.20) menyatakan bahwa ada 2 faktor yang mempengaruhi guru dalam melaksanakan tugas keprofesionalannya yaitu faktor internal dari diri guru dan faktor eksternal dari lingkungannya. Khusus untuk penelitian ini, lebih dilihat dari faktor internal guru yaitu tingkat pendidikan dan keikutsertaan pelatihan (diklat) tentang Kurikulum 2013.

Perubahan Kurikulum 2013 pada umumnya menuntut peningkatan kualitas layanan guru. Kualitas layanan guru ini sangat penting dalam meningkatkan kualitas pendidikan di Indonesia. Menurut Bank Dunia ada beberapa tantangan yang dihadapi Indonesia seperti rendahnya kualifikasi pendidik dan sumber daya manusia pendidikan, ketidaksetaraan latar belakang pendidikan guru dan rendahnya kesejahteraan guru (Setyarahajoe \& Irtanto, 2013). Mengenai kualifikasi pendidik, Amirrachman (2014) menyatakan bahwa hanya $37 \%$ dari 3,5 juta guru berkualifikasi minimum Sarjana atau Diploma-IV sesuai undang-undang. Artinya kualitas pendidikan guru-guru di Indonesia masih rendah, terlihat dari masih sedikit yang memenuhi standar pendidikan minimum. Pentingnya kualifikasi akdemik ini di jelaskan dari hasil penelitian Hamzah (2010) yang menyebutkan bahwa ada dampak yang cukup dan sangat signifikan dari faktor latar belakang pendidikan terhadap keprofesionalan guru.

Guru dituntut untuk profesional dalam menjalankan perannya sebagai seorang pen- 
didik. Secara formal yang terjadi di sekolah untuk menjadi professional, guru disyaratkan memenuhi kualifikasi akademik minimum dan bersertifikat pendidik. Menurut Peraturan Menteri Nomor 16 Tahun 2007 tentang Standar Kualifikasi dan Kompetensi Guru, guru pada SMA/MA harus memiliki jenjang pendidikan minimum diploma empat (D-IV) atau sarjana (S-1) program studi yang sesuai dengan mata pelajaran yang diampu, dan diperoleh dari program studi yang terakreditasi.

Tingkat pendidikan guru diperlukan untuk meningkatkan kinerjanya. Goldhaber \& Brewer (1996, p.208) menyatakan bahwa "it is possible that only science teachers who have Master's degrees in science will improve student science achievement substantially. On the other hand, science teachers with a master's degree in a subject other than science will not have great impact on student science achievement". Goldhaber \& Brewer menjelaskan bahwa guru sains yang memiliki gelar master sains akan mampu meningkatkan prestasi sains siswa secara substansial dibandingkan dengan guru bukan berlatar belakang pendidikan sains. Hal ini berarti harus adanya kecocokan atau linieritas antara tingkat pendidikan dengan mata pelajaran yang diajarkan oleh guru di sekolah.

Selain tingkat pendidikan, untuk meningkatkan kinerja guru juga diperlukan aspek pendidikan dan pelatihan mengajar yang cukup. Pendidikan dan pelatihan meliputi pengalaman dalam mengikuti kegiatan pendidikan dan pelatihan dalam rangka pengembangan atau peningkatan kompetensi dalam melaksankan tugas sebagai pendidik baik pada tingkat kecamatan, kabupaten/kota, provinsi, maupun nasional. Dalam penelitian ini, pendidikan dan pelatihan yang dimaksud adalah frekuensi pendidikan dan pelatihan yang diikuti guru mengenai implementasi Kurikulum 2013 berupa kegiatan sosialisasi, bimtek, DDTK Kurikulum 2013, diklat guru fisika Kurikulum 2013 maupun workshopworkshop oleh MGMP fisika atau madrasah.

Hasil wawancara dengan kepala bidang Kurikulum Pendidikan Madrasah di Kanwil Kementerian Agama Daerah Istimewa Yogyakarta, Nadhif (2014) menyatakan bahwa dalam mempersiapkan pelaksanaan Kurikulum 2013 di Madrasah, Kanwil DIY telah memberikan pelatihan mengenai Kurikulum 2013 baik melalui sosialisasi maupun Bimtek kepada 3252 guru MI, MTs dan MA pada tahun 2013. Pelaksanaan sosialisasi selama 2 hari dan Bimtek selama 4 hari dirasa sangat singkat dan diduga belum mampu memberi pemahaman implementasi Kurikulum 2013 secara utuh kepada warga sekolah.

Proses pembelajaran fisika perlu diupayakan agar menekankan pada pemberian pengalaman belajar langsung untuk mengembangkan kompetensi, tujuannya agar peserta didik mampu dan memahami hakikat fisika yang dilandasi sikap ilmiah untuk memecahkan masalah yang dihadapinya. Hakikat pembelajaran fisika ini sejalan dengan landasan berpikir dalam implementasi Kurikulum 2013 yang dalam proses pembelajarannya menekankan pada penggunaan pendekatan ilmiah (scientific approach). Perencanaan dalam pembelajaran fisika merupakan hal yang sangat penting dimana peran guru meliputi 3 hal yaitu perencana, pelaksana dan evaluator. Seorang guru sebagai pelaksana kurikulum baik dalam merencanakan, melaksanakan dan mengevaluasi diharapkan dapat meningkatkan prestasi belajar peserta didik agar peserta didik mendapat manfaat dalam belajar (Mallo, 2013).

Proses pembelajara diatur dalam Peraturan Permendikbud Nomor 65 Tahun 2013 tentang Standar Proses Pendidikan dan Permendikbud Nomor 59 Tahun 2014 tentang desain pembelajaran Kurikulum 2013 Sekolah Menengah Atas/Madrasah Aliyah. Proses pembelajaran pada satuan pendidikan memuat perencanaan pembelajaran, pelaksanaan pembelajaran serta penilaian proses pembelajaran.

Implementasi Kurikulum 2013 akan bermuara pada pelaksanaan pembelajaran yaitu bagaimana agar isi atau pesan-pesan kurikulum dapat dicerna oleh peserta didik. Menurut Majid (2006, p.7) ada 3 kemampuan yang harus dikuasai guru dalam mengimplementasikan pelaksanaan pembelajaran. Pertama adalah kemampuan menyusun rencana pembelajaran, meliputi: mampu mendeskripsikan tujuan pembelajaran, mampu memilih/menentukan materi, mampu mengorganisir materi, mampu menentukan metode/strategi pembelajaran, mampu menentukan sumber belajar/media/alat pembelajaran, mampu menyusun perangkat penilaian dan mampu mengalokasikan waktu. Kemampuan kedua adalah kemampuan melaksanakan pembelajaran, meliputi: mampu membuka pelajaran, mampu menyajikan materi, mampu menggunakan metode/strategi/alat peraga, mampu menggunakan bahasa yang komunikatif, mampu memotivasi siswa dan berinteraksi dengan siswa secara komunikatif, mampu menyimpulkan pembelajaran, mampu memberikan umpan balik, mampu 
melaksanakan penilaian dan mampu mengalokasikan waktu. Kemampuan ketiga adalah kemampuan mengadakan evaluasi pembelajaran, meliputi: mampu membuat dan memilih soal, mampu memeriksa jawaban, mampu mengolah serta menganalisis hasil penilaian, mampu mengidentivikasi variasi hasil penelitian, dan mampu menyimpulkan hasil penilaian secara jelas dan logis.

Untuk dapat terlaksananya standar proses pembelajaran dengan baik, faktor kompetensi guru yang sesuai dengan kurikulum perlu menjadi perhatian, serta kesiapan guru berkaitan dengan pemahaman proses pembelajaran maupun kesiapan dalam perangkat pembelajaran sebagai pendukung. Kesiapan guru yang berkaitan dengan latar belakang akademik belum teridentifikasi, Pada implementasi kurikulum, adanya hambatan-hambatan dalam pembelajaran perlu segera dicari pemecahannya. Dalam hubungan ini persoalan yang digali adalah respon guru fisika saat mengimplementasikan Kurikulum 2013.

Berdasarkan latar belakang yang telah diuraikan, penelitian ini dilakukan untuk mengkaji sejauh mana keterlaksanaan standar proses dalam implementasi pembelajaran fisika memuat kurikulum 2013 di MAN pilot project DIY berdasarkan latar belakang akademik guru. Wujud keterlaksanaannya dikaji dari tingkat keberhasilan seorang guru yang diukur berdasarkan indikator pemahaman guru terhadap kurikulum yang berlaku, penguasaan terhadap perencanaan, pelaksanaan dan penilaian pembelajaran, upaya yang dilakukan dalam meningkatkan kualitas pembelajaran serta kendalakendala yang diperkirakan menjadi hambatan dalam melaksanakan pembelajaran fisika dalam mengimplementasikan Kurikulum 2013.

\section{METODE}

\section{Jenis Penelitian}

Penelitian ini termasuk penelitian survei dengan pendekatan kuantitatif dan kualitatif.

\section{Waktu dan Tempat Penelitian}

Penelitian dilaksanakan di Madrasah Aliyah Negeri pilot project di DIY yang melaksanakan Kurikulum 2013 tahun pelajaran 2014/2015 yaitu MAN 1 Yogyakarta, MAN 2 Yogyakarta, MAN 3 Yogyakarta, MAN Wonokromo, MAN Wates 2 dan MAN Wonosari. Penelitian dilaksanakan empat bulan, yaitu dari bulan Februari sampai dengan Mei 2015.

\section{Target/Subjek Penelitian}

Berdasarkan data ada 6 Madrasah Aliyah Negeri di DIY yang merupakan pilot project Kurikulum 2013. Subjek penelitian adalah 7 guru fisika yang mengajar di kelas X. Pengambilan sampel guru dilakukan dengan teknik purposive sampling dari 16 guru fisika yang mengajar di MAN pilot project DIY.

\section{Intrumen, dan Teknik Pengumpulan Data}

Instrumen pengumpulan data dalam penelitian ini meliputi lembar angket, lembar observasi, lembar penilaian dokumen, dan pedoman wawancara. Instrumen disusun berdasarkan kisikisi agar instrumen yang digunakan memenuhi validitas isi dan validitas konstruk.

\section{Teknik Analisis Data}

Data yang diperoleh dianalisis dengan menggunakan teknik deskriptif kuantitatif dan deskripsi kualitatif. Analisis deskriptif kualitatif digunakan untuk menganalisis data berupa catatan hasil wawancara dan kejadian penting selama observasi proses pembelajaran selama penelitian. Analisis deskripsi kuantitatif dilakukan untuk menganalisis data berupa hasil penelitian angket, observasi dan dokumentasi.

Langkah-langkah dalam teknik analisis data angket, observasi dan dokumentasi adalah tabulasi data, menghitung skor dari masingmasing instrumen, dan menggubah skor menjadi nilai dengan kriteria. Kriteria atau kategori tingkat kecenderungan mengacu pada table modifykasi skala Likert menjadi 4 kriteria yang dikembangkan oleh Direktorat Pembinaan SMA (2010, pp. 59-60) yang diadaptasi seperti tertera pada Tabel 1 halaman 5. Pada angket hambatan yang dialami guru, kriterianya diubah menjadi tidak ada hambatan, ada sedikit hambatan, cukup ada hambatan dan ada banyak hambatan.

Tabel 1. Kriteria Tingkat Kecenderungan*)

\begin{tabular}{lll}
\hline No & $\begin{array}{l}\text { Rentang Skor (Mean } \\
\text { Pembanding) }\end{array}$ & Kriteria \\
\hline 1 & $\begin{array}{l}\mathrm{Mi}+1,5 \mathrm{SBi}<\mathrm{M} \leq \mathrm{Mi}+3,0 \\
\mathrm{SBi}\end{array}$ & Sangat Baik \\
2 & $\mathrm{Mi}+0 \mathrm{SBi}<\mathrm{M} \leq \mathrm{Mi}+1,5$ & Baik \\
& $\mathrm{SBi}$ & Kurang Baik \\
3 & $\mathrm{Mi}-1,5 \mathrm{SBi}<\mathrm{M} \leq \mathrm{Mi}+0$ & $\mathrm{SBi}$ \\
4 & $\mathrm{Mi}-3 \mathrm{SBi}<\mathrm{M} \leq \mathrm{Mi}-1,5$ & Sangat Kurang \\
& $\mathrm{SBi}$ & Baik \\
\hline
\end{tabular}

*) Sumber: Direktorat Pembinaan SMA, 2010

Dengan $\mathrm{Mi}=$ mean ideal dan $\mathrm{SBi}=$ simpangan baku ideal. 
Teknik analisis kualitatif untuk memperkuat data kuantitatif dilakukan dengan analisis model Miles \& Huberman (Miles \& Huberman, 1994, p.10). Analisis Miles \& Huberman dengan cara mereduksi data (penggolongan data), menampilkan data, dan membuat kesimpulan (verifikasi data). Adapun data yang dapat diperoleh dari pendekatan kualitatif yaitu berdasarkan data dari wawancara dan kejadian penting selama observasi proses pembelajaran selama penelitian. Kesimpulan akhir diperoleh dengan menggunakan tiangulasi data terhadap variable penelitian dari masing-masing instrumen yang digunakan dalam pengumpulan data penelitian.

\section{HASIL DAN PEMBAHASAN}

\section{Latar Belakang Akademik}

Terkait dengan latar belakang akademik responden guru fisika ada dua indikator utama yang diungkap dalam penelitian ini, yaitu tingkat pendidikan terakhir (S-1/S-2/S-3) dan kegiatan pendidikan dan pelatihan yang pernah diikuti guru. Secara rinci deskripsi latar belakang akademik responden dapat dijelaskan sebagai berikut.

Tingkat pendidikan responden menunjukkan jenjang pendidikan terakhir yang ditempuh oleh guru yang bersangkutan, terangkum pada Tabel 2.

Tabel 2. Deskripsi Tingkat Pendidikan

\begin{tabular}{cccc}
\hline No & Pendidikan Terakhir & Frekuensi & \% \\
\hline 1 & S-1 & 5 & 71 \\
2 & S- 2 & 2 & 29 \\
\hline
\end{tabular}

Pendidikan dan pelatihan yang dimaksud yaitu mengenai frekuensi diklat yang pernah diikuti oleh guru terkait Kurikulum 2013, terangkum dalam Tabel 3.

Tabel 3. Deskripsi Diklat yang pernah diikuti

\begin{tabular}{llll}
\hline No & Pendidikan/Pelatihan & Frekuensi & $\%$ \\
\hline 1 & Tidak pernah & 0 & 0 \\
2 & 1-3 kali $(\mathrm{X})$ & 3 & 43 \\
3 & Lebih dari 3 kali (Y) & 4 & 57 \\
\hline
\end{tabular}

Aspek Pemahaman Guru

Data angket guru menunjukkan bahwa pada aspek pemahaman Kurikulum 2013 semua responden yakni 7 guru berada pada rentang skor 68,25 dan 84 , artinya semua guru memiliki pemahaman yang sangat baik terhadap Kurikulum 2013.
Tabel 4. Skor Pemahaman Guru

\begin{tabular}{ccccc}
\hline No & Kode Guru & Nama Madrasah & Skor & Ket \\
\hline 1 & A & Madrasah 1 & 84 & SB \\
2 & B & Madrasah 2 & 75 & SB \\
3 & C & Madrasah 3 & 77 & SB \\
4 & D & Madrasah 4 & 73 & SB \\
5 & E & Madrasah 5 & 79 & SB \\
6 & F & Madrasah 5 & 69 & SB \\
7 & G & Madrasah 6 & 83 & SB \\
\hline
\end{tabular}

Keterangan: SB $=$ Sangat Baik

Hasil wawancara menunjukkan semua responden memahami dengan baik tujuan dan elemen perubahan pada Kurikulum 2013.

\section{Aspek Perencanaan}

Tabel 5. Keterlaksanaan Perencanaan Ditinjau dari Tingkat Pendidikan Guru

\begin{tabular}{|c|c|c|c|c|c|c|c|}
\hline \multirow{2}{*}{ No } & \multirow{2}{*}{$\mathbf{T P}$} & \multicolumn{4}{|c|}{ Perencanaan } & \multirow[t]{2}{*}{ Ket } & \multirow[t]{2}{*}{ Kesm } \\
\hline & & Guru & Kri & Dok & Kri & & \\
\hline 1 & \multirow{5}{*}{ S-1 } & 88 & SB & 81 & SB & SB & \multirow[t]{5}{*}{ Baik } \\
\hline 2 & & 69 & B & 93 & SB & B & \\
\hline 3 & & 63 & B & 96 & SB & B & \\
\hline 4 & & 75 & B & 96 & SB & B & \\
\hline 5 & & 96 & SB & 88 & SB & SB & \\
\hline \multicolumn{2}{|c|}{ Rerata } & 78 & & 91 & & & \multirow{4}{*}{ Baik } \\
\hline 6 & S-2 & 67 & B & 85 & SB & B & \\
\hline 7 & & 88 & SB & 88 & SB & SB & \\
\hline & rata & 78 & & 87 & & & \\
\hline
\end{tabular}

Keterangan: Kri $=$ kriteria, Ket $=$ keterangan, Kesm $=$ kesimpulan, $\mathrm{B}=$ baik dan $\mathrm{SB}=$ sangat baik.

Data angket guru, review dokumen (dok) perencanaan pada RPP berdasarkan tingkat pendidkan guru terangkum pada Tabel 5 halaman 5. Data angket guru, review dokumen (dok) perencanaan pada RPP berdasarkan frekuensi keikutsertaan diklat guru terangkum pada Tabel 6.

Tabel 6. Keterlaksanaan Perencanaan Ditinjau dari Keikutsertaan Diklat

\begin{tabular}{|c|c|c|c|c|c|c|c|}
\hline \multirow{2}{*}{ No } & \multirow{2}{*}{$\mathbf{T P}$} & \multicolumn{4}{|c|}{ Perencanaan } & \multirow[t]{2}{*}{ Ket } & \multirow[t]{2}{*}{ Kesm } \\
\hline & & Guru & Kri & Dok & Kri & & \\
\hline 1 & $\mathrm{X}$ & 88 & SB & 81 & $\mathrm{SB}$ & SB & Baik \\
\hline 2 & & 63 & B & 96 & SB & B & \\
\hline 3 & & 75 & B & 96 & SB & B & \\
\hline \multicolumn{2}{|c|}{ Rerata } & 75 & & 91 & & & \\
\hline 4 & $\mathrm{Y}$ & 67 & B & 85 & SB & B & Baik \\
\hline 5 & & 88 & SB & 88 & SB & SB & \\
\hline 6 & & 69 & B & 93 & SB & B & \\
\hline 7 & & 96 & SB & 88 & SB & SB & \\
\hline & & 80 & & 89 & & & \\
\hline
\end{tabular}

Keterangan: $X=$ frekuensi diklat rendah $(1-3$ kali), $\mathrm{Y}=$ frekuensi siklat tinggi (lebih dari 3 
Jurnal Inovasi Pendidikan IPA, 2 (1), 2016 - 81

Ninik Uswatun Fadilah, Suparwoto

kali), Kri $=$ kriteria, Ket $=$ keterangan, Kesm $=$ kesimpulan, $\mathrm{B}=$ baik dan $\mathrm{SB}=$ sangat baik.

\section{Aspek Pelaksanaan}

Tabel 7. Keterlaksanaan Pelaksanaan Ditinjau dari Tingkat Pendidikan Guru

\begin{tabular}{|c|c|c|c|c|c|c|c|c|}
\hline \multirow{2}{*}{ No } & \multirow{2}{*}{ TP } & \multicolumn{6}{|c|}{ Pelaksanaan } & \multirow{2}{*}{ Kes } \\
\hline & & $\mathbf{G}$ & Kri & $\mathbf{S}$ & Kri & $\mathbf{O}$ & Kri & \\
\hline 1 & \multirow[t]{5}{*}{ S-1 } & 76 & $\mathrm{~B}$ & 69 & $\mathrm{~B}$ & 83 & SB & \multirow{6}{*}{ Baik } \\
\hline 2 & & 71 & $\mathrm{~B}$ & 78 & B & 80 & B & \\
\hline 3 & & 61 & KB & 81 & B & 80 & B & \\
\hline 4 & & 75 & $\mathrm{~B}$ & 72 & $\mathrm{~B}$ & 66 & B & \\
\hline 5 & & 83 & SB & 80 & B & 78 & B & \\
\hline \multicolumn{2}{|c|}{ Rerata } & 73 & & 76 & & 77 & & \\
\hline 6 & $\mathrm{~S}_{-}$-2 & 73 & $\mathrm{~B}$ & 76 & $\mathrm{~B}$ & 81 & B & \multirow{3}{*}{ Baik } \\
\hline 7 & S-2 & 87 & SB & 81 & SB & 92 & SB & \\
\hline \multicolumn{2}{|c|}{ Rerata } & 80 & & 79 & & 87 & & \\
\hline
\end{tabular}

Keterangan: Kri $=$ kriteria, Kes $=$ kesimpulan, $\mathrm{SB}=$ sangat baik, $\mathrm{B}=$ baik dan $\mathrm{KB}=$ kurang baik

Tabel 8. Keterlaksanaan Pelaksanaan Ditinjau dari Keikutsertaan Diklat

\begin{tabular}{lcccccccc}
\hline \multirow{2}{*}{ No } & \multirow{2}{*}{ TP } & \multicolumn{7}{c}{ Pelaksanaan } \\
\cline { 3 - 7 } & & G & Kri & S & Kri & O & Kri & \\
\hline 1 & & 76 & B & 69 & B & 83 & SB & Baik \\
2 & X & 61 & KB & 81 & B & 80 & B & \\
3 & & 75 & B & 72 & B & 66 & B & \\
Rerata & 71 & & 74 & & 76 & & \\
4 & & 73 & B & 76 & B & 81 & B & Baik \\
5 & Y & 87 & SB & 81 & SB & 92 & SB & \\
6 & & 71 & B & 78 & B & 80 & B & \\
7 & & 83 & SB & 80 & B & 78 & B & \\
Rerata & 79 & & 79 & & 83 & & \\
\hline
\end{tabular}

Keterangan: $X=$ frekuensi diklat rendah $(1-3$ kali), $\mathrm{Y}=$ frekuensi siklat tinggi (lebih dari 3 kali), Kri = kriteria, Kes = kesimpulan, $\mathrm{SB}=$ sangat baik, $\mathrm{B}=$ baik dan $\mathrm{KB}=$ kurang baik.

Data angket guru $(\mathrm{G})$, observasi $(\mathrm{O})$ dan angket siswa (S) berdasarkan tingkat pendidikan guru terangkum pada Tabel 7 dan berdasarkan frekuensi keikutsertaan diklat terangkum pada Tabel 8.

\section{Aspek Penilaian}

Data angket guru, review dokumen (dok) penilaian pada RPP berdasarkan tingkat pendidikan guru terangkum pada Tabel 9 .
Tabel 9. Keterlaksanaan Penilaian Ditinjau dari Tingkat Pendidikan Guru

\begin{tabular}{lccccccc}
\hline \multirow{2}{*}{ No } & \multirow{2}{*}{ TP } & \multicolumn{4}{c}{ Penilaian } & Ket & Kesm \\
\cline { 3 - 8 } & & Guru & Kri & Dok & Kri & & \\
\hline 1 & & 75 & B & 64 & B & B & Baik \\
2 & & 67 & B & 99 & SB & B & \\
3 & S-1 & 54 & KB & 58 & KB & KB & \\
4 & & 71 & B & 58 & KB & KB & \\
5 & & 96 & SB & 73 & B & B & \\
Rerata & 73 & & 70 & & & \\
6 & S-2 & 71 & B & 58 & B & B & Baik \\
7 & & 79 & B & 79 & B & B & \\
\multicolumn{2}{l}{ Rerata } & 75 & & 69 & & & \\
\hline
\end{tabular}

Keterangan: Kri= kriteria, Ket = keterangan,

Kesm $=$ kesimpulan, $\mathrm{SB}=$ sangat baik, $\mathrm{B}=$ baik dan $\mathrm{KB}=$ kurang baik

Data angket guru, review dokumen RPP berdasarkan frekuensi keikutsertaan diklat guru terangkum pada Tabel 10.

Tabel 10. Keterlaksanaan Penilaian Ditinjau dari Keikutsertaan Diklat

\begin{tabular}{|c|c|c|c|c|c|c|c|}
\hline \multirow{2}{*}{ No } & \multirow{2}{*}{$\mathbf{T P}$} & \multicolumn{4}{|c|}{ Penilaian } & \multirow[t]{2}{*}{ Ket } & \multirow[t]{2}{*}{ Kesm } \\
\hline & & Guru & Kri & Dok & Kri & & \\
\hline 1 & $\mathrm{X}$ & 75 & $\mathrm{~B}$ & 64 & $\mathrm{~B}$ & $\mathrm{~B}$ & Kurang \\
\hline 2 & & 54 & KB & 58 & KB & KB & Baik \\
\hline 3 & & 71 & $\mathrm{~B}$ & 58 & KB & KB & \\
\hline \multicolumn{2}{|c|}{ Rerata } & 67 & & 60 & & & \\
\hline 4 & & 71 & B & 58 & B & B & \\
\hline 5 & \multirow[t]{3}{*}{ Y } & 79 & B & 79 & B & B & \\
\hline 6 & & 67 & B & 99 & SB & B & Baik \\
\hline 7 & & 96 & B & 73 & B & B & \\
\hline \multicolumn{2}{|c|}{ Rerata } & 78 & & 77 & & & \\
\hline
\end{tabular}

Keterangan: $\mathrm{B}=$ baik, $\mathrm{SB}=$ sangat baik, $\mathrm{KB}=$ kurang baik, $\mathrm{Kri}=$ kriteria, $\mathrm{X}=$ frekuensi diklat rendah $(1-3$ kali), $\mathrm{Y}=$ frekuensi siklat tinggi (lebih dari 3 kali), Ket $=$ keterangan, Kesm = kesimpulan.

\section{Hambatan}

Data angket guru menunjukkan bahwa pada aspek hambatan dalam implementasi Kurikulum 2013 sebanyak 3 guru berada pada rentang skor antara 62,5 dan 81,25 sehingga berada pada kategori ada sedikit hambatan. 4 guru berada pada rentang skor antara 43,75 dan 62,5 sehingga berada pada kategori cukup ada hambatan.

Rangkuman skor hambatan guru dalam mengimplementasikan Kurikulum 2013 pada mata pelajaran fisika terangkum pada Tabel 11 halaman 7. 
Tabel 11. Skor Hambatan Guru

\begin{tabular}{ccccc}
\hline No & $\begin{array}{c}\text { Kode } \\
\text { Guru }\end{array}$ & $\begin{array}{c}\text { Nama } \\
\text { Madrasah }\end{array}$ & Skor & Ket \\
\hline 1 & A & Madrasah 1 & 61 & CAH \\
2 & B & Madrasah 2 & 61 & CAH \\
3 & C & Madrasah 3 & 63 & ASH \\
4 & D & Madrasah 4 & 66 & ASH \\
5 & E & Madrasah 5 & 50 & CAH \\
6 & F & Madrasah 5 & 55 & CAH \\
7 & G & Madrasah 6 & 76 & ASH \\
\hline
\end{tabular}

Keterangan:

$\mathrm{CAH}=$ cukup ada hambatan, $\mathrm{ASH}=$ Ada sedikit hambatan.

\section{Upaya}

Data angket guru menunjukkan bahwa pada aspek upaya meningkatkan pemahaman mengenai Kurikulum 2013 sebanyak 2 guru berada pada rentang skor lebih dari 19,5 sehingga masuk kategori sangat baik, 4 guru berada pada skor antara 15 sampai 19,5 sehingga berada pada kategori baik dan 1 guru berada pada skor antara 10,5 sampai 15 sehingga berada pada kategori kurang baik.

Tabel 12. Skor Upaya Guru

\begin{tabular}{ccccc}
\hline No & Kode Guru & Nama Madrasah & Skor & Ket \\
\hline 1 & A & Madrasah 1 & 11 & KB \\
2 & B & Madrasah 2 & 20 & SB \\
3 & C & Madrasah 3 & 16 & B \\
4 & D & Madrasah 4 & 18 & B \\
5 & E & Madrasah 5 & 17 & B \\
6 & F & Madrasah 5 & 15 & B \\
7 & G & Madrasah 6 & 23 & SB \\
\hline
\end{tabular}

Keterangan:

$\mathrm{SB}=$ sangat baik, $\mathrm{B}=$ baik, $\mathrm{KB}=$ kurang baik

Hasil dari pemrosesan data yang dilakukan oleh peneliti menunjukkan bahwa keterlaksanaan proses pembelajaran fisika berdasarkan latar belakang akademik guru di MAN pilot project DIY masuk dalam kriteria baik.

Hasil data mengenai pemahaman Kurikulum 2013 menunjukkan bahwa reponden selaku guru fisika kelas $\mathrm{X}$ memahami dengan baik salah satu komponen dari kurikulum 2013 yakni pemahaman mengenai Kurikulum 2013. Pemahaman tersebut diantaranya meliputi rasionaliasi perubahan, tujuan Kurikulum, elemen perubahan, Standar Kompetensi Lulusan, Standar Isi, Standar Proses Pembelajaran dan Standar Penilaian.

Hasil wawancara peneliti dengan responden memperkuat hasil data dari angket tersebut. Semua responden dapat menjelaskan tujuan kurikulum, elemen perubahan, Standar Kompetensi Lulusan, Standar Isi dan Standar Penilaian, meskipun dengan menggunakan kalimat yang berbeda tetapi memiliki maksud yang sama.

Elemen perubahan dalam Kurikulum 2013 meliputi perubahan standar kompetensi lulusan, standar proses, standar isi, dan standar penilaian (Kemdikbud, 2012). Semua responden menyatakan, bahwa elemen perubahan dalam kurikulum 2013 mengalami pembaharuan yang cukup signifikan daripada KTSP. Namun demikian, elemen perubahan khususnya standar isi kurikulum 2013 pada hakekatnya tidaklah berbeda materi dengan KTSP. Isi materi yang ada dalam standar isi antara kurikulum 2013 dan KTSP hakekatnya sama, hanya saja berbeda urutannya. Sebagai contoh, materi fluida statis. Dalam KTSP, materi tersebut diajarkan untuk kelas XI, pada kurikulum 2013 diajarkan untuk kelas X.

Hasil data penelitian berupa angket dan wawancara dengan responden menunjukkan bahwa semua responden memahami Standar Kompetensi Lulusan dengan baik. Adapun SKL tersebut dibedakan menjadi tiga domain, yaitu domain sikap, keterampilan, dan pengetahuan.

Data tambahan berupa data dari hasil wawancara dengan Kepala Madrasah maupun Wakil Kepala bidang Kurikulum juga menunjukkan mengenai kesiapan guru dalam memahami Kurikulum 2013. Hal ini dikarenakan semua guru sudah mengikuti pelatihan atau bimtek yang diselenggarakan oleh Kemenag maupun masing-masing madrasah serta forum MGMP.

Perencanaan pembelajaran diamati dengan menggunakan data angket responden, hasil wawancara dan review dokumen RPP. Berikut pemaparan hasil perencanaan pembelajaran dari ketiga sumber tersebut. Data angket responden diperoleh 3 guru masuk kategori sangat baik dan 4 guru dengan kategori baik. Semua responden dapat menjawab angket dengan baik mengenai identitas, indikator, tujuan, materi dan skenario pembelajaran.

Hasil wawancara dengan responden menunjukkan bahwa hampir semua responden menyampaikan waktu ideal membuat RPP adalah diawal semester sebelum proses pembelajaran dimulai. Namun demikian, pada realitasnya RPP dikerjakan sebagian diawal semester dan sisanya dikerjakan selama proses pembelajaran. Kondisi ini terjadi karena keterbatasan waktu yang dimiliki oleh responden seandainya keseluruhan RPP dikerjakan di awal semester. 


\section{Jurnal Inovasi Pendidikan IPA, 2 (1), 2016 - 83}

Ninik Uswatun Fadilah, Suparwoto

Hasil review dokumen RPP menunjukkan bahwa aspek perencanaan 7 orang responden atau $100 \%$ populasi responden berada pada kategori sangat baik. RPP tersebut dibuat secara bersama-sama dalam forum MGMP Madrasah dan Diknas.

Berdasarkan hasil analisi data pada Tabel 5 untuk aspek perencanaan pembelajaran yang dikelompokkan dari jenjang pendidikan guru diperoleh nilai rerata persentase sama besar antara S-1 dan S-2 yaitu 78\%. Pada aspek penilaian dokumen RPP terlihat bahwa guru S-2 memiliki rerata skor keterlaksanaan perencanaan penilaian lebih rendah dari pada guru S-1. Dari hasil wawancara dan kuesioner terungkap bahwa adanya ketidak linieran jurusan yang diambil oleh guru S-2 dengan jurusan saat S-1.

Untuk aspek perencanan pembelajaran yang dikelompokkan dari frekuensi keikutsertaannya mengikuti diklat Tabel 6 rerata persentase guru yang frekuensi keikutseraan diklat tinggi (Y) memperoleh rerata lebih besar $(80 \%)$ dari pada guru dengan frekuensi keikutserataan diklat kurang $(75 \%)$. Hal ini cukup beralasan, lebih berpengalamannya guru dalam kegiatan pelatihan akan meningkatkan mutu profesionalisme guru selain tentunya mampu meng-up date dan menginformasikan hal-hal baru menyangkut kebijakan pendidikan maupun perkembangan terkini konsep pembelajaran. Dari angket guru juga terungkap ada 3 guru yang pernah mengikuti diklat tingkat nasional di Jakarta.

Pelaksanaan pembelajaran terdiri atas kegiatan awal (pendahuluan), kegiatan inti dan kegiatan akhir (penutup) yang di dalamnya terdapat aspek pendekatan saintifik dan penilaian otentik seperti tuntutan Kurikulum 2013. Keterlaksanaan proses pelaksanaan pembelajaran fisika oleh guru di MAN pilot project DIY diungkap melalui instrumen berupa angket guru, wawancara, observasi dan angket siswa. Hasil analisi secara keseluruhan menyimpulkan keterlaksanaannya dalam kategori baik.

Hasil analisis penilaian angket guru diperoleh rerata persentase keterlaksanaan sebesar 75\% dengan kategori baik. Hasil tersebut didukung oleh rerata persentase skor observasi yaitu $80 \%$ dengan kategori baik, dan rerata skor angket siswa yang menunjukkan nilai 165,6 dengan kategori baik.

Dari data wawancara dengan guru diperoleh informasi bahwa beberapa responden menyatakan belum sepenuhnya menggunakan pendekatan saintifik karena keterbatasan waktu. Responden menyatakan terkadang membutuh- kan waktu yang cukup lama untuk membimbing siswa dalam $5 \mathrm{M}$, padahal waktu yang tersedia untuk penyampaian materi sangat terbatas. Akan tetapi ada kepercayaan diri dan harapan dari responden, jika sudah terbiasa maka kedepannya pembelajaran akan berjalan lancar. Selain itu diperoleh informasi bahwa pemilihan metode pembelajaran disesuaikan dengan kompetensi dan materi yang harus dikuasi siswa serta waktu yang tersedia. Tak jarang agar pembelajaran berjalan sesuai dengan tujuan yang direncanakan responden melakukan improvisasi metode dari rencana awal pembelajaran di RPP.

Wawancara juga dilakukan dengan kepala madrasah. Menurut kepala madrasah guru telah mampu melaksanakan pembelajaran sesuai dengan rencana yang dibuatnya. Penjelasan kepala madrasah ini didukung data dari supervisi yang telah dilakukan baik itu oleh kepala atau pengawas. Dari kepala madrasah juga diperoleh informasi bahwa untuk madrasah rintisan unggulan (RMU) diadakan pendampingan dalam implementasi Kurikulum 2013 mulai dari perencanaan, pelaksanaan dan penilaian oleh instruktur dari Balai Diklat Kemenag maupun oleh pengawas mapel dari Diknas. Sehingga tidak mengherankan jika pelaksanaanya sudah baik.

Dari Tabel 7 tentang keterlaksanaan berdasarkan jenjang pendidikan guru dan Tabel 8 tentang keterlaksanaan pembelajaran berdasarkan frekuensi keikutsertaan diklat menunjukkan keterlaksanan pembelajaran fisika berdasarkan latar belakang akademik guru masuk dalam kategori baik. Tabel 7 menunjukkan bahwa guru yang jenjang pendidikannya lebih tinggi (S-2) memiliki nilai persentase keterlaksanaan pembelajaran fisika yang lebih tinggi dibandingkan guru dengan jenjang pendidikan S-1. Hal ini dapat dilihat dari selisih rata-rata persentase keterlaksanaan proses pembelajaran fisika antara guru S-2 dan S-1 yang kecil yaitu 7\% pada angket guru, 3\% pada angket siswa, dan 10\% pada observasi. Artinya jenjang pendidikan dapat mencerminkan kompetensi guru, tingkat pendidikan guru yang tinggi dapat mentrasfer ilmu kepada siswa. Kompetensi yang dimaksud disini adalah keterlaksanaan proses pembelajaran fisika.

Dari Tabel 8 tentang keterlaksanaan berdasarkan pengalaman mengikuti pelatihan (diklat) terlihat bahwa guru yang frekuensi keikutsertaan diklat tinggi memiliki nilai persentase keterlaksanaan pelaksanaan pembelajaran fisika yang lebih tinggi dibanding guru yang keikusertaan pelatihannya kurang. Hal ini dapat 


\section{Jurnal Inovasi Pendidikan IPA, 2 (1), 2016 - 84}

Ninik Uswatun Fadilah, Suparwoto

dilihat dari selisih rata-rata persentase keterlaksanaan proses pembelajaran fisika antara guru frekuensi keikutsertaan pelatihan tinggi dan kurang yaitu $8 \%$ pada angket guru, 5\% pada angket siswa, dan $7 \%$ pada observasi. Salah satu fakta dilapangan berupa hasil observasi dalam pembelajaran menunjukkan bahwa guru yang frekuensi keikutsertaan diklatnya tinggi jauh dapat mengelola kelas dengan baik. Seperti kita ketahui bahwa pelatihan guru memiliki tujuan untuk meningkatkan knowledge (pengetahuan), skills (keterampilan) dan attitude (sikap). Pelatihan juga menyegarkan dan menginformasikan hal-hal baru, baik menyangkut kebijakan pendidikan maupuan perkembangan terkini konsep pembelajaran. Mengingat perkembangan ilmu pengetahuan yang demikian pesat dan dinamis, guru perlu meng-up date pengetahuannya secara terus-menerus sehingga tidak ketinggalan atau gagap menghadapi perubahan. Pengalaman diklat berpengaruh dalam meningkatkan mutu profesionalisme guru.

Keterlaksanaan penilaian pembelajaran fisika oleh guru di MAN pilot project DIY diungkap melalui instrumen berupa angket guru, wawancara, dan dokumentasi. Angket guru memberikan rerata skor 17,57 (73\%) dengan kategori baik. Hasil ini didukung data dokumen penilaian pada RPP dengan rerata skor 28 $(70 \%)$.

Penilaian yang digunakan yaitu penilaian otentik yang meliputi proses dan hasil. Pelaksanaan penilaian pada mata pelajaran fisika meliputi 3 kompetensi yaitu kompetensi sikap, pengetahuan dan ketrampilan. Semua respoden (7 orang) telah melakukan perencanaan penilaian sikap, pengetahuan dan keterampilan, responden juga telah membuat soal dan pedoman penskoran. Responden A, B, C, D, dan G telah menyiapakan LKPD.

Dari Tabel 9 tentang keterlaksanaan penilaian berdasarkan jenjang pendidikan guru menunjukkan keterlaksanan penilaian pembelajaran fisika berdasarkan jenjang pendidikan guru baik itu S-1 maupun S-2 masuk dalam kategori baik. Tabel 9 menunjukkan bahwa guru yang jenjang pendidikannya lebih tinggi (S-2) memiliki nilai persentase keterlaksanaan penilaian pembelajaran fisika yang lebih tinggi dibandingkan guru dengan jenjang pendidikan S-1. Hal ini dapat dilihat dari selisih rata-rata persentase keterlaksanaan penilaian proses pembelajaran fisika antara guru S-2 dan S-1 yaitu $2 \%$ pada angket guru. Artinya jenjang pendidikan dapat mencerminkan kompetensi guru, tingkat pendidikan guru yang tinggi dapat mentrasfer ilmu kepada siswa. Namun demikian pada aspek penilaian rencana penilaian di RPP terlihat bahwa guru S-2 memiliki rerata skor keterlaksanaan lebih rendah dari pada guru S-1. Dari hasil wawancara dan kuesioner terungkap bahwa adanya ketidak linieran jurusan yang diambil oleh guru S-2 dengan jurusan saat S-1.

Dari Tabel 10 tentang keterlaksanaan penilaian berdasarkan pengalaman mengikuti pelatihan (diklat) menunjukkan keterlaksanan penilaian pembelajaran fisika untuk frekuensi keikutsertaan diklat yang kurang masuk dalam kategori kurang baik sedangkan frekuensi keikutsertaan diklat tinggi masuk dalam kategori baik. Tabel 10 menunjukkan bahwa guru yang frekuensi keikutsertaan diklat tinggi memiliki nilai persentase keterlaksanaan penilaian pelaksanaan pembelajaran fisika yang lebih tinggi dibanding guru yang keikusertaan pelatihannya kurang. Hal ini dapat dilihat dari selisih rata-rata persentase keterlaksanaan penilaian pembelajaran fisika antara guru frekuensi keikutsertaan pelatihan tinggi dan kurang yaitu $11 \%$ pada angket guru dan $7 \%$ pada analisis dokumen penilaian di RPP.

Salah satu fakta dilapangan berupa hasil observasi dalam pembelajaran menunjukkan bahwa guru yang frekuensi keikutsertaan diklatnya tinggi jauh dapat mengelola kelas dengan baik. Hasil tersebut didukung data wawancara bahwa sebagian guru menjelaskan teknik dan bentuk penilaian yang akan dilakukan terhadap siswa. Permasalahan yang mereka hadapi dalam mengapliksikan instrumen penilaian dibicarakan secara bersama dalam MGMP. Dari hasil observasi, dalam penilaian performance responden $\mathrm{B}$ membuat kesepakatan dengan siswa terhadap point penilaian yang akan mereka lakukan untuk penilaian antar teman. Proses pelibatan siswa ini merupakan proses pemberian feedback yang berdampak pada peningkatan proses pembelajaran siswa. Peningkatan proses yang dimaksud adalah bahwa sikap siswa yang semula bergantung terhadap guru sebagai satu-satunya sumber keputusan tentang kualitas pembelajaran menuju kepada situasi yang lebih mandiri dan independen.

Situasi yang mandiri dan independen tersebut memungkinkan setiap individu siswa mengembangkan pengalamannya serta mengembangkan penilaian terhadap pembelajaran mereka sendiri. Ini berarti siswa tidak saja diberikan kesempatan untuk melakukan refleksi terhadap hasil pekerjaan temannya, akan tetapi juga 


\section{Jurnal Inovasi Pendidikan IPA, 2 (1), 2016 - 85}

Ninik Uswatun Fadilah, Suparwoto

terhadap hasil pekerjaan mereka sendiri. Penilaian terjadi dalam interaksi antara guru dan siswa. Dalam penilaian otentik, dorongan dan motivasi dalam berbagai bentuknya termasuk dengan cara memberikan feedback secara tepat sangat dibutuhkan untuk meningkatkan kualitas pembelajaran siswa. Siswa perlu mengetahui mengapa dia melakukan kekeliruan, apa sumber kesalahan yang dilakukan dan bagaimana cara mencari solusi atas kesalahan yang dilakukan. Untuk keperluan ini, feedback dengan cara sebagimana tersebut di atas adalah sudah sangat tepat.

Hambatan guru dalam mengimplementasikan Kurikulum 2013 di MAN pilot project DIY diungkap melalui instrumen berupa angket guru dan wawancara. Hasil penelitian dari angket yang tercantum pada Tabel 11 menunjukkan bahwa ada hambatan yang dihadapi guru fisika MAN pilot project DIY dalam implementasi kurikulum 2013. Berdasarkan angket hambatan yang dihadapi guru masuk dalam kategori cukup ada hambatan dengan skor rerata 62. Dari analisis skor item diperoleh informasi skor terendah yaitu 14 , hal ini berkaitan dengan adanya pernyataan dari responden menenai keterbatasan akses terhadap buku/modul panduan tentang model-model pembelajaran yang disarankan dilakukan dengan pendekatan saintifik. Responden merasa kesulitan dalam memperoleh buku/ modul/panduan tentang model pembelajaran PBL dan PjBL.

Ketersediaan buku/modul/panduan mengenai $\mathrm{PBL}$ dan $\mathrm{PjBL}$ sangat penting karena pada Kurikulum 2013 guru diharapkan melaksanakan pembelajaran dengan pendekatan saintifik dimana dalam pendekatan saintifik tersebut dapat menggunakan model PBL dan PjBL yang dapat mengaktifkan siswa.

Hambatan selanjutnya adalah mengenai pernyataan tentang pembuatan instrument penilaian kompetensi keterampilan dimana responden merasa kesulitan dalam pembuatan instrument penilaian portofolio. Pada Kurikulum 2013 portofolio merupakan salah satu teknik penilaian yang dilakukan dalam penilaian pembelajaran. Penilaian ini penting dimana dengan portofolio dapat diperlihatkan hasil perkembangan siswa dari waktu ke waktu terkait kumpulan hasil kerjanya.

Berdasarkan wawancara terhadap responden dan kepala madrasah juga diperoleh informasi faktor yang menghambat pelaksanaan Kurikulum 2013 pada pembelajaran antara lain: terbatasnya waktu sehingga penggunaan berba- gai metode dengan pendekatan saintifik belum bisa berlangsung secara optimal, adanya madrasah yang alat dan bahan laboratoriumnya belum tersedia dengan lengkap sehingga dalam pembelajaran kurang bisa berjalan dengan efektif karna keterbatasan peralatan tersebut.

Tabel 12 memberikan informasi bahwa sebanyak 6 guru dari 7 guru fisika telah memiliki upaya yang baik dalam meningkatkan pemahaman tentang standar proses dalam implementasi pembelajaran fisika, sehingga dapat dikatakan bahwa $86 \%$ guru fisika telah melakukan upaya baik dalam meningkatkan pemahaman maupun kualitas pembelajaran implementasi Kurikulum 2013. Upaya yang dilakukan meliputi mengikuti pelatihan-pelatihan yang diselenggarakan oleh pemerintah maupun secara mandiri dari kesadaran guru sendiri supaya paham dalam mengimplementasikan perubahan tersebut di pembelajaran.

Data angket upaya guru mengenai upaya guru secara mandiri melalui $\mathrm{CD}$, buku, media cetak atau media internet dan atau berdiskusi dengan teman sejawat (MGMP) mencari informasi tentang rasionalisasi Kurikulum 2013, pendekatan saintifik dan penilaian otentik memperoleh skor paling tinggi yaitu 23. Hal ini menunjukkan bahwa guru telah sangat baik berupaya mencari informasi guna meningkatkan pemahaman mengenai Kurikulum 2013. Data angket mengenai berdiskusi dalam forum MGMP menyamakan persepsi dan pengembangan perangkat pembelajaran fisika (Silabus dan RPP) dengan pendekatan saintifik memperoleh skor 21. Hal ini menunjukkan bahwa upaya guru dalam mencari informasi tentang pengembangan perangkat pembelajaran fisika dengan pendekatan saintifik sangat baik. Skor terendah diperoleh pada data angket no 4 yaitu mengenai keikutsertaan guru dalam workshop atau pelatihan penilaian otentik dengan skor 17.

Selain dengan angket untuk aspek upaya juga diperoleh dari data wawancara dengan kepala madrasah. Upaya yang dilakukan madrasah diantaranya dengan membeli buku pendamping dari penerbit, pihak sekolah mensosialisasikan jika ada peraturan baru kepada bapak/ibu guru, pengiriman guru untuk mengikuti MGMP, workshop maupun bimtek pembelajaran dan penilaian kurikulum 2013 mapel fisika, adanya pendampingan oleh pengawas atau instruktur dari Balai Diklat Kemenag. 


\section{SIMPULAN DAN SARAN}

\section{Simpulan}

Pemahaman guru fisika di MAN pilot project di Yogyakarta mengenai Kurikulum 2013 berada pada kategori sangat baik. Perencanaan guru fisika di MAN pilot project di Yogyakarta berada pada kategori baik. Pelaksanaan pembelajaran oleh guru fisika di MAN pilot project di Yogyakarta berada pada kategori baik. Penilaian guru fisika di MAN pilot project di Yogyakarta berada pada kategori baik. Upaya guru fisika di MAN pilot project di DIY yaitu mencari informasi melalui $\mathrm{CD}$, buku, media cetak atau media internet dan atau berdiskusi dengan teman sejawat (MGMP) mencari informasi tentang rasionalisasi kurikulum 2013, pendekatan saintifik, perangkat pembelajaran dan penilaian otentik. Upaya yang dilakukan madrasah diantaranya dengan mengadakan workshop/pelatihan, membeli buku pendamping, dan mensosialisasikan jika ada peraturan baru kepada guru. Hambatan yang dihadapi guru dalam melaksanakan proses pembelajaran fisika implementasi Kurikulum 2013 di MAN pilot project di DIY yaitu kurangnya ketersediaan buku mengenai model pembelajaran PBL, PjBL; guru kesulitan dalam membuat instrumen penilaian portofolio; dan guru belum maksimal dalam memfungsikan instrumen penilaian sikap sebagai mana mestinya.

\section{Saran}

Guru fisika MAN diharapkan mulai menyesuaikan diri untuk beradaptasi melaksanakan Kurikulum 2013. Guru sebaiknya memfungsikan instrumen penilaian sikap sebagai mana mestinya, misalnya dengan menggunakan nomor dada atau pin sehingga siswa lebih mudah dikenali dan dihafal. Pihak madrasah memfasilitasi guru untuk mengembagnkan diri meningkatkan kualitas pembelajaran fisika, dengan rekomendasi kegiatan pembelajaran yang relevan maupun peningkatan saranan prasarana seperti menyediakan buku/modul tentang pendekatan saintifik.

\section{DAFTAR PUSTAKA}

Amirrachman, A. (2014, November 26). GIP: Kualifikasi pendidikan guru di Indonesia rendah. Diakses tanggal 20 Agustus 2015, dari Bisnis.com http://kabar24.bisnis.com/read/2014112 6/255/275628/gip-kualifikasi pendidikan-guru-di-indonesia-rendah
Arikunto, S. (2009). Dasar-dasar evaluasi pendidikan. Jakarta: Bumi Aksara.

Cheung, A.C., \& Wong P. M. (2011). Factors affecting the implementation of curriculum reform in Hong Kong. International Journal of Educational Management, 26 (1), 39-54.

Direktorat Profesi Pendidik. (2010). Ramburambu pengembangan kegiatan $K K G$ dan MGMP. Direktorat Jenderal Peningkatan Mutu Pendidik dan Tenaga Kependidikan Kementerian Pendidikan Nasional.

Goldhaber, D. D. \& Brewer, D. J. (1996). Evaluating the effect of teacher degree level on educational performance. Diambil pada tanggal 2 Mei 2015, dari http://nces.ed.gov/pubs97/975351.pdf

Hamzah, A. (2010). Dampak faktor latar belakang pendidikan, pengalaman pelatihan, beban kerja, pengalaman mengajar, dan kemampuan kognitif guru terhadap keprofesionalan guru biologi tentang laboratorium pada SMA di Kabupaten Aceh Besar. Diakses tanggal 5 Juni 2014 dari http://karyailmiah.um.ac.id/index.php/disertasi/artic le/view/7304

Kemdikbud. (2012a). Bahan uji publik kurikulum 2013, tentang tujuan pendidikan nasional.

Kemdikbud. (2012b). Bahan uji publik kurikulum 2013, tentang rasional kurikulum 2013 PPT-1.1.

Kunandar. (2013). Penilaian autentik (penilaian hasil belajar peserta didik berdasarkan kurikulum 2013). Jakarta: PT Raja Grafindo Persada.

Majid, A. (2006). Perencanaan pembelajaran: mengembangkan standar kompetensi guru. Bandung: PT Remaja Rosdakarya.

Mallo, I. Y. (2013). Analysis of teacher's perception of their public image and it influence on students performance in physics: A key to improving the quality of education in Nigeria. Journal of Social Sciences, 4 (12), 113.

Mendiknas. (2007). Peraturan Menteri Pendidikan Nasional Nomor 16 Tahun 2007 tentang Kualifikasi Akademik dan Kompetensi Guru. 


\section{Jurnal Inovasi Pendidikan IPA, 2 (1), 2016 - 87}

Ninik Uswatun Fadilah, Suparwoto

Miles, M. B., \& Huberman, A. M. (1994). Qualitative data analysis. Beverly Hills: Sage Publication,Inc.

Nadhif. (2014). Pelaksanaan bimtek Kurikulum 2013 di Kanwil Kemenag DIY. (Wawancara pribadi, pada hari Selasa, 8 Juli 2014 di Jogjakarta)

Purnomo. (2014). Implementasi Kurikulum 2013 dalam pembelajaran di sekolah dasar. Diakses tanggal 28 Juni 2014, dari http://prosiding.upgrismg.ac.id/index.ph p/pgsd/pgsd/paper/viewFile/323/275

Setyarahajoe, R., \& Irtanto. (2013). The competence of teacher as human resources at senior high school of Kediri City East Java Province. Academic Research International, 4 (2), 252-261. 